\title{
Comparison of Similarities and Differences between Two Forums of Art and Literature
}

\author{
Kaili Wang ${ }^{1,2}$ \\ ${ }^{1}$ Marxism School, Chongqing Normal University, Chongqing, 401331, China \\ ${ }^{2}$ Marxism School, Chinese Academy of Social Sciences, Beijing, 102488, China
}

Keywords: Art and Literature, Forum, Similarities and Differences, Enlightenment

\begin{abstract}
There are differences between two forums, from the aspect of time, location, background of times, purpose, significance, language of times. However, there are similarities among differences. The similarities lie in that, two forums offer high location for literary and artistic work, show the way for literary and artistic work, and also point out major routes and creative techniques for the literary and artistic creation. By sorting out the similarities and differences of two forums, it can be found that, both of them are guided by Marxism, which are products of Marxism literary and artistic theory in different historical periods of China. They can be traced to the same origin while having different breakthroughs, which have important enlightenment for the construction and development of modern China.
\end{abstract}

\section{Introduction}

In the middle of October, 2014, Xi Jinping held the Forum of Art and Literature in Beijing, which was 72 years later than Speech at the Forum of Art and Literature in Yan'an. Both of these two forums have similarities in the aspect of time, location, background of times and purpose. However, there are similarities among differences.The similarities lie in that, two forums offer high location for literary and artistic work, show the way for literary and artistic work, and also point out major routes and creative techniques for the literary and artistic creation. By sorting out the similarities and differences of two forums, it can be found that, both of them are guided by Marxism, which are products of Marxism literary and artistic theory in different historical periods of China. They can be traced to the same origin while having different breakthroughs, which have important enlightenment for the construction and development of modern China.

\section{Similarities and Differences of Context: War and Peace}

Forum of Art and Literature in Yan'an was opened during anti-Japanese war period in May, 1942. More than 80 persons attended the forum. Chairman Mao gave the Speech at the Forum of Art and Literature in Yan'an. Speech at the Forum of Art and Literature in Beijing was the one held in October, 2014, when the reform of China entered the deep-water period since the $18^{\text {th }}$ National Congress of the Communist Party of China. More than 70 persons attended the forum. During the forum, Xi Jinping gave an important speech. Two forums were held in different years, which meant that the background of times was different, the task of times to be resolved was different, the language of times to be applied was different and the historical significance was different as well.

Anti-Japanese and Reform. Different time nodes means that the background of times is different. From the international perspective, Speech at the Forum of Art and Literature in Yan'an was held during World War II, when the World Anti-Fascist War was most fierce. From domestic perspective, the anti-Japanese situation was abnormally hard, but dogmatism of inner party had certain impact. The central party was implementing the "Rectification Movement", including improving party conduct, studying conduct and writing conduct. From the background of literature and art industry, literary and art circle of Yan'an at that time was generally active and progressive. However, from garret(a small,dark back room over a kitchen dark back room over a kitchen) to revolutionary base, it transcended two areas and historical times, which needed the transformation of 
values and thinking modes. However, some literary and art workers did not make changes in time, thus some tendencies came into being, including dissatisfaction of current situation, negligence of practice, far from the mass and "literary sectarianism".

Liberation and Renaissance. Different backgrounds of times of two forums determine the different purposes of holding these forums. As the purpose of forum in Yan'an, it offers specific formulation in the introduction, namely to let literature and art better serve the central work of that time-- defeat Japanese imperialism, realize national liberation. During the years of revolutionary war, literary work was required to serve the revolution. In a similar way, the times of peaceful construction cannot be separated from the literary work as well, moreover, China has been in the critical period of deepening the reform, building a moderately prosperous society in all respects and realizing the great revival of the Chinese nation. Otherwise, there is no horn for calling upon times to move forward, and also no social mores leading us.

Saving the Nation from Extinction and Guiding. Different backgrounds of times and purposes of two forums determine the different historical significance. Forum in Yan'an not only developed the literary theory of Marxism, but also armed the minds of literary and art workers with proletariat thoughts, which let the concept of Chinese workers' and peasants' creation deep into minds of people, and also fatherly promoted the literary and artistic creation to be lifestyle and popular. After the forum, a large group of literary works sprung up, which were closely combined with the revolutionary struggle and production practice, thus they masses were delighted to hear and see those works, such as The White-haired Girl, Marriage of Xiao Er'hei, The Sun Shines Over the SANGGAN River, etc. They gave full play of the positive role of revolutionary literature and art in self-help production project and anti-Japanese national salvation movement at that time.

Language of Wartime and Peace Discourse. Every times has its own language. During the times of revolutionary war, the police came into the first place, thus the language of wartime was closely related to the politics. During the Forum of Art and Literature in Yan'an, Chairman Mao took the politics as the first standard for literary criticism and put the artistic standard into the second place, who demanded "unification of politics and art, unification of content and form, unification of revolutionary political contents and perfect artistic form as much as possible"[1]. During the Forum of Art and Literature in Beijing, Xi Jinping mentioned that creation of excellent products is the key task of literary and art workers, "literary and art workers need to constantly perfect the creation...devote great efforts to creating excellent products organically integrated of ideology, art and enjoyment."[2] In Modern Chinese Dictionary, ideology refers to the political tendency expressed by the literary works or other works. Political standard is the basis for measuring the ideology of a product. During the forum, Xi Jinping used “ideology" to replace "politics", which embodies that times language of peacetime was totally different from that of revolutionary war times. Content of ideology(or politics) varies with the times. During Forum of Art and Literature in Yan'an, Chairman Mao considered that, based on political standard, "Everything is good, as long as it facilitates the resistance of Japanese and unity, encourages the masses to dedicate themselves heart and soul to the same cause, rejects the regression and promotes the progress." [1] During Forum of Art and Literature in Beijing, Xi Jinping considered that ideology embodied the highest state of art. Good literary and art products can enlighten the thoughts and cultivate the life. Specifically speaking, the ideology is expressed in the following aspects: the first is to hold the banner of socialism core values high. The second is to carry forward the main theme of patriotism and guide people to set up and stick to correct national values. The third is to pass on upward and good values, guide people to strengthen the ability of moral judgment and sense of moral honor and improve the moral realm.

\section{The Same Essence: Values and Orientation}

Although these two forums have so many differences as above, there are similarities among differences. Both of them are some response to the social phenomenon, especially the literary and art phenomenon, which show the way, the major paths and creative methods for literary and art work. Both leaders have realized the ideological nature of literary work. From the perspective of national strategy, focus on the literary and art work has huge reaction on the economy, politics and society. 


\section{Mutual Connection: The Same Strain while Remaining Breakthroughs}

By sorting out the similarities and differences of two forums, it can be found that, both of them are guided by Marxism, which are products of Marxism literary and artistic theory in different historical periods of China. They are Marxism literary theories with Chinese features. There is relationship of inheritance and development between them. On one hand, it embodies the influence of Chairman Mao's governing idea on Xi Jinping, on the other hand, it embodies that socialist theoretical system with Chinese characteristics is the inheritance and development of Marxism and Mao Zedong Thought.

Both Forums are guided by Marxism, one after another, the Same Strain. Marxism is the foundation of our Party and country and the fundamental principle of Marxism is the guide of all works. Economic basis decides the superstructure and the superstructure reacts on the economic basis. Based on the dialectical relationship, both two forums offer high positions of literary and art work from the perspective of ideology and superstructure; the masses are the main body of history, the main body of practice and the creators of history. Based on the mass view, two forums point out the orientation of literary and art work serving the mass and socialism, point that going deep into the mass is the major literary and art creation path to learn from the people; both positive and negative parts are contained in the thing. New things are developed on the basis of old things by positive sublation. On the dialectical negation, both forums advocate that literary and art work need to be good at positive sublation and innovation. It can be seen that, these two forums have the same philosophical foundation and class stand, which are guided by Fundamental Principles of Marxism. Both of them are successively connected with each other, coming from the same strain.

Two Forums are different because of the times, the latter is the breakthrough and development of the former. Due to concrete times backgrounds, these two forums have different concrete purposes and meanings. Besides, languages used in these two forums are marked with the brands of times, which make different footnotes and development for the Marxism literary theories with Chinese features. However, if we extend the time into the long river of history and widen the space into the global view, we can find that, two forums were held aimed at the changes of ideology determined by the objective international and domestic existence during the great retrieval of the Chinese nation. On the basis of respecting the comparatively independent objective rules of literary and art work, we can better give the play of literary and art as the ideology. By the artistry and enjoyment, highlight of the literary and art works' ideology is to "teach through lively activities", "moisten things silently", further to play the role of motivating and guiding the masses, forming the common ideology and concentrating on gathering the strength. Thus they can better respond to the voice of times respectively, complete tasks of times respectively and constantly open the path for healthy social development. It can be seen that, differences of these two forums are only exterior appearances. They have the same essence. There are similarities among differences, differences among similarities. Forum of Art and Literature in Beijing is the breakthrough and development of spirit of Forum of Art and Literature in Beijing under a specific context in modern times.

\section{Enlightenment of Two Forums on the Contemporary Era}

Characteristics of Literary and Art Work Determine the Necessity to Strengthen the Literary and Art Work. During two forums, literary and art work are highly located, which originate from the characteristics of literary and art work. Those characteristics not only include image, aesthetics and thought, but also ideological nature. Just because of characteristics of literature and art, we should strengthen the construction of literature and art work and culture while carrying out the socialist modernization.

With the rapid development of Chinese economy and huge achievements, it is urgently needed to construct the international power of discourse and influential power, which are embodied as the soft strength of one country. Soft strength is the ability to achieve the purpose by attraction not force. Culture of one country is one important source of soft strength. Literature and art is an important component of culture. Highlight of soft strength cannot be separated from the prosperous and 
powerful culture taking literature and art as the carrier. It can be seen that, literature and art is related to the cultural construction of one country, the international competence and attraction of one country, and also the ideological struggle internationally. Consequently, we should clearly realize the characteristics of ideology of literature and art, so as to positively strengthen the literature and art work during the socialist modernization.

Party Committees, governments and related Departments at all Levels and Literary and Art Workers should Possess Literary Consciousness, positively Put that into Practice. Both forums start from the characteristics of literature and art and attach much importance to the literature and art work, which offer important enlightenment for our current construction. First of all, party committees and governments and related departments should possess literary consciousness. Firstly, we should focus on that ideologically, carefully learns and master relevant literary and art spirits and policies of the central party, and also positively organize the deployment and implementation. Secondly, on the basis of sticking to the direction of "literature and art serves for the people, for the socialism", we should improve the policies and systems, increase the investment and strengthen the talent cultivation and supporting degree of literature and art work. Secondly, we should stick to the policy of "Letting a hundred flowers bloom, a hundred schools of thought contend", carry forward the literature and art democracy, respect and trust literary and art workers, and then create an easy atmosphere for artists to make innovations.

Secondly, literary and art workers should possess literary consciousness. First of all, they should ideologically recognize that their images and literary and art works play the exemplary role of clarifying the air, carrying forward the spirit and communicating the socialist core values and positive energy. They should clearly understand that literary and art work have huge reaction on economy, politics and society. Secondly, they should consciously stick to the artistic idea and become the "illuminati, forerunner and promoter of social mores" in practice [2]. Thirdly, they should strengthen learning, master and respect the objective rules of literary and art generation and creation, create more excellent products close to the people and life. The products are enjoyed by the masses.

Sticking to Mao Zedong Thoughts, Constantly Enriching and Improving Socialist Theory with Chinese Characteristics. Two different periods and forums of literary and art are different phenomenons, but with the same essence. Both forums originate from the guidance of Marxism. The success of Chinese revolution cannot be separated from the guidance of Marxism, which cannot give the play unless by integration with Chinese reality. Mao Zedong is the crystal of Marxism with Chinese features. The success of Chinese reform and opening up, and the socialist modernization cannot be separated from the guidance of socialist theoretical system with Chinese characteristics, while the formation of socialist theoretical system with Chinese characteristics cannot be separated from the nutrition of Mao Zedong thought. Mao Zedong Thought lays a solid theoretical foundation for the formation of socialist theoretical system with Chinese characteristics. Under the circumstance of abnormally fierce international competition and the general strategical layout of Chinese "four comprehensives"(Comprehensively build a moderately prosperous society, Comprehensively deepen reform, Comprehensively govern the nation according to law, Comprehensively strictly govern the Party), we cannot be separated from the guidance of Mao Zedong Thought, let along three active souls of Mao Zedong Thought. We should constantly absorb nutrients from Mao Zedong Thought, constantly enrich and improve the socialist theoretical system with Chinese characteristics, so as to promote the great retrieval of the Chinese nation to be realized earlier.

\section{Acknowledgments}

This paper is the program of national social science fund, the title is: Research on Citizenship Education and National Identity, Serial No.14BSH001.

\section{References}

[1] Selected Works of Mao Zedong, the 3rd volume, People's Publishing House, the 2nd edition of 1991. 
[2] Sticking to the people-oriented creation and creating more excellent products living up to the times, People's Daily, the 1st edition of Oct. 16th, 2014. 